\title{
Hubungan Asupan Gizi, Pemberian Asi Eksklusif, dan Pengetahuan Ibu dengan Status Gizi (Tb/U) Balita 6-59 Bulan
}

\author{
Bertalina ${ }^{1}$, Amelia P.R ${ }^{2}$ \\ ${ }^{1,2}$ Jurusan Gizi, Politeknik Kesehatan Tanjungkarang, Indonesia \\ Email: ubertalina@yahoo.com
}

\begin{abstract}
Correlation Between Nutritional Intake, Exclusive Breastfeeding, and Mother's Knowledge With Nutrition Status (TB/U) for Children 6-59 Months. Stunting prevalence in Indonesia is $37,2 \%$, whereas in Bandar Lampung City is $44,6 \%$ and in Kemiling District is $39,6 \%$. This study was to determine the risk factors associated with children nutritional status (TB/U) in Beringin Jaya, Kemiling. This analytical survey research was using cross-sectional design. Population in this study were 1141 toddlers, and 88 as respondents. Cluster Sampling was used to determine the respondents. Data was analyzed Univariate and Bivariate. This research was conducted in Beringin Jaya, Kemiling. The result showed that 19 toddlers (21.6\%) were identified stunting and $69(78.4 \%)$ toddlers were normal. There was no correlation between energy intake with nutritional status $(\mathrm{TB} / \mathrm{U})$ with $\mathrm{p}$-value $=0,175$. There was a correlation between protein intake with nutritional status $(\mathrm{TB} / \mathrm{U})$ with $\mathrm{p}$-value $=0,022$. There was no correlation between exclusive breastfeeding and nutritional status $(\mathrm{TB} / \mathrm{U})$ with $\mathrm{p}$-value $=0.758$. There was no correlation between mother's knowledge of nutritional status $(\mathrm{TB} / \mathrm{U})$ with value $\mathrm{p}$-value $=1,000$. It was suggested that Public Health Centers and Integrated Service Center should improve its activities that related with Exclusive Breastfeeding through counseling and Breastfeeding food demonstration to society, especially mothers, the knowledge of healthy and nutritious breastfeeding food for children. It was also suggested that Public Health Centers and Integrated Service Center should improve its activities on the importance of the golden period of 1000 days, especially for childbearing age women and pregnant women in order to reduce the risk of stunting.
\end{abstract}

Keywords: Food intake, Exclusive breastfeeding, Mother's knowledge, Nutritional status

\begin{abstract}
Abstrak: Hubungan Asupan Asupan Gizi, Pemberian Asi Eksklusif, dan Pengetahuan Ibu dengan Status Gizi (TB/U) Balita. Prevalensi masalah gizi stunting di Indonesia sebesar 37,2\%, sedangkan di Kota Bandar Lampung sebesar 44,6\% dan di Kecamatan Kemiling sebesar $39,6 \%$. Penelitian ini bertujuan untuk mengetahui faktor risiko yang berhubungan dengan status gizi balita (TB/U) di Kelurahan Beringin Jaya Kecamatan Kemiling. Jenis penelitian ini adalah survei analitik dengan rancangan cross sectional. Populasi dalam penelitian ini balita umur 659 bulan dengan jumlah 1141 balita dan jumlah sampel 88. Teknik pengambilan sampel pada penelitian ini yaitu menggunakan Cluster Sampling. Analisa data yang digunakan dalam penelitian ini adalah Univariat dan Bivariat.Penelitian ini dilakukan di Kelurahan Beringin Jaya Kecamatan Kemiling. Hasil penelitian, sebesar 19 balita $(21,6 \%)$ dengan status gizi pendek dan $69(78,4 \%)$ balita dengan status gizi normal. Tidak ada hubungan antara asupan energi dengan status gizi $(\mathrm{TB} / \mathrm{U})$ dengan nilai $\mathrm{p}=0,175$. Ada hubungan antara asupan protein dengan status gizi $(\mathrm{TB} / \mathrm{U})$ dengan nilai $p$-value $=0,022$. Tidak ada hubungan antara pemberian ASI Eksklusif dengan status gizi $(\mathrm{TB} / \mathrm{U})$ dengan nilai $p$-value $=0,758$. Tidak ada hubungan antara pengetahuan ibu dengan status gizi $(\mathrm{TB} / \mathrm{U})$ dengan nilai $p$-value $=1.000$. Diharapkan puskesmas dan posyandu dapat meningkatkan kegiatan yang berkaitan dengan penyuluhan mengenai ASI Eksklusif dan demonstrasi pembuatan Makanan Pendamping ASI (MP-ASI) agar masyarakat memahami cara pembuatan MP-ASI yang sehat dan bergizi untuk anak. Diharapkan puskesmas dan posyandu dapat meningkatkan kegiatan penyuluhan mengenai pentingnya periode emas 1000 hari kehidupan khususnya bagi wanita usia subur dan ibu hamil agar menurunkan resiko anak stunting.
\end{abstract}

Kata kunci: Asupan, Pemberian ASI eksklusif, Pengetahuan ibu, Status gizi

Pembangunan kesehatan dalam periode tahun 2015-2019 difokuskan pada empat program prioritas yaitu penurunan angka kematian ibu dan bayi, penurunan prevalensi balita stunting, pengendalian penyakit menular dan pengendalian penyakit tidak menular. Upaya peningkatan status gizi masyarakat termasuk penurunan prevalensi balita pendek menjadi 
salah satu prioritas pembangunan nasional. Target penurunan prevalensi stunting (pendek dan sangat pendek) pada anak baduta (dibawah 2 tahun) adalah menjadi 28\% (RPJMN, 20152019). Stunting merupakan suatu masalah yang sedang dihadapi di dunia ini.

Menurut data WHO 2012, terdapat sebanyak 162 juta anak usia di bawah 5 tahun (balita) mengalami stunting. Anak dengan tinggi badan pendek atau sangat pendek, akan memberi dampak negatif terhadap perkembangan anak selanjutnya. Anak-anak pendek yang akan tumbuh menjadi dewasa kemungkinan lebih besar untuk berprestasi pendidikan yang buruk, miskin, kurang sehat dan lebih rentan terhadap penyakit tidak menular. Oleh karena itu, anak pendek merupakan prediktor buruknya kualitas sumber daya manusia yang diterima secara luas, yang selanjutnya menurunkan kemampuan produktif suatu bangsa di masa yang akan datang (Unicef, 2012).

Anak stunting merupakan hasil kronis gizi buruk dan kondisi lingkungan yang buruk. Kondisi stunting pada anak dapat dicegah dengan cara meningkatkan status gizi ibunya pada masa remaja dan wanita subur, pemberian makanan bayi dan anak yang tepat, serta meningkatkan akses air bersih dan sanitasi yang memadai, imunisasi dan pengobatan untuk penyakit manula (WHO, 2016).

Anak-anak berisiko lebih besar stunting jika mereka lahir di daerah pedesaan, rumah tangga miskin atau ibu yang pendidikan rendah. Misalnya, di 66 survei nasional dari LMIC dari tahun 2005, prevalensi stunting pada anak-anak yang lahir dari ibu yang tidak memiliki pendidikan sebesar $38,7 \%$ sedangkan dengan prevalensi anak stunting yang lahir dari ibu yang menyelesaikan sekolah menegah sebesar $23,4 \%$ (WHO, 2016).

Stunting pada anak disebabkan oleh kurang nutrisi pada ibu hamil dan asupan yang kurang pada bayi dan anak. Stunting dapat menyebabkan manifestasi klinis jangka pendek dalam bidang kesehatan berupa peningkatan mortalitas dan morbiditas, dalam bidang perkembangan anak berupa penurunan perkembangan kognitif, motorik ,dan bahasa, dan juga dibidang ekonomi dapat meningkatkan pengeluaran dalam biaya kesehatan. Manifestasi klinis jangka panjang dalam bidang kesehatan berupa perawakan yang pendek, peningkatan obesitas, dan penurunan kesehatan reproduksi, dalam bidang perkembangan anak berupa penurunan kapasitas belajar, dan dalam bidang ekonomi dapat menyebabkan penurunan kemampuan kerja dan produktivitas (WHO, 2016).

Berdasarkan data Riskesdas 2013, angka prevalensi stunting di Indonesia pada anak balita adalah $37,2 \%$ (18\% sangat pendek dan $19,2 \%$ pendek), meningkat dari tahun 2007 sebesar $(35,6 \%)$ menjadi $(36,8 \%)$ pada tahun 2010. Prevalensi stunting di Indonesia lebih tinggi daripada negara-negara di Asia Tenggara, seperti Malaysia (17,2\%), Brunei Darusalam $(19,7 \%)$, Filipina $(30,3 \%)$ dan Thailand $(16,3 \%)$ (WHO, 2016).

Provinsi Lampung merupakan salah satu dari 15 provinsi dengan prevalensi balita pendek diatas prevalensi nasional, dengan angka kejadian pendek sebesar 42,6\% (Riskesdas, 2013). Berdasarkan Profil Kesehatan Lampung 2014 menunjukan prevalensi balita pendek pada yaitu Lampung Tengah 52,7\% (38,6 sangat pendek dan 14,1 pendek), Pesawaran 50,8\% (sangat pendek $33,5 \%$ dan pendek $17,3 \%$ ), dan Bandar Lampung 44,6\% (sangat pendek 30,3 dan pendek 14,3\%).

Berdasarkan survey penilaian status gizi di Bandar Lampung tahun 2014, menunjukan persentase status balita pendek dan pendek yang terdapat di Rajabasa 55,6 \% (sangat pendek $28 \%$ dan pendek 27,6\%), Kemiling 39,6\% (sangat pendek 18,7\% dan pendek 20,9\%), Sukabumi $35,3 \%$ (sangat pendek $17,5 \%$ dan pendek 17,8\%).

Berdasarkan penelitian Jeanette (2014) bahwa asupan energi balita di wilayah kerja puskesmas Tumiming kota Manado yang dikatergorikan cukup $(30,9 \%)$ dan yang rendah $(69,1 \%)$. Hasil bivariat yang diperoleh nilai $p=$ $<0,05$ yang menunjukkan ada hubungan yang bermakna antara asupan energi dengan kejadian stunting pada balita di wilayah kerja puskesmas Tumining kota Manado.

Berdasarkan penelitian Anisa (2012), asupan protein balita di Kelurahan Kalibiru sebanyak $(89,4 \%)$ cukup dan $(10,6 \%)$ rendah. Hasil bivariat diperoleh nilai $p=0,011 \quad(\mathrm{p}<0,05)$ yang menunjukan adanya hubungan yang bermakna antara asupan protein dengan kejadian stunting pada balita di Kalibiru.

Berdasarkan penelitian Terati (2013), pemberian ASI eksklusif didapatkan balita tidak ASI eksklusif sebanyak $87,8 \%$ dan $12,2 \%$ balita yang mendapatkan ASI eksklusif, dari hasil uji statistik diperoleh nilai $(p<0,05)$ yang menunjukan ada hubungan yang bermakna antara pemberian ASI eksklusif dengan kejadian stunting pada balita di wilayah kerja Dinkes Kota Palembang. 
Berdasarkan penelitian Marniasih (2015) menunjukkan $100 \%$ ibu batita yang berpengetahuan kurang seluruhnya memiliki balita stunting. Dari 9 ibu batita berpengetahuan cukup ada $(66,7 \%)$ batita mengalami stunting, sisanya $33,3 \%$ batita mengalami stunting, sedangkan dari 25 ibu batita yang berpengetahuan baik seluruh batitanya tidak mengalami stunting. Berdasarkan uji statistik chi-square diperoleh $p$ value $=0,0001$ diinterpretasikan ada hubungan antara tingkat pengetahuan ibu dengan kejadian stunting pada batita di Desa Pandan Indah.

Data Puskesmas Beringin Raya di Kecamatan Kemiling terdapat $56,1 \%$ balita yang mempunyai status gizi di Bawah Garis Merah (BGM) yaitu berada di wilayah Kelurahan Beringin Jaya.

Berdasarkan uraian di atas, pada usia balita masih banyak terdapat masalah gizi yang dialami, salah satunya adalah pendek dan sangat pendek (stunting) sehingga peneliti ingin melihat asupan energi, asupan protein, pemberian asi eksklusif dan Pengetahuan ibu dengan Status Gizi (TB/U) pada balita (6-59 bulan) di Kelurahan Beringin Jaya Kecamatan Kemiling.

\section{METODE}

Jenis penelitian ini adalah analitik dengan rancangan penelitian cross sectional. Populasi penelitian adalah balita umur 6-59 bulan yang berjumlah 1.141 anak. Sampel dalam penelitian ini adalah sebagian balita baik laki-laki ataupun perempuan yang memenuhi kriteria inklusi sebagai berikut:

a. Balita berusia 6-59 bulan yang bertempat tinggal di wilayah penelitian.

b. Ibu balita bersedia menjadi responden dalam penelitian ini.

Jumlah sampel yang dibutuhkan dalam penelitian ini ditentukan dengan menggunakan rumus Lemeshow (1997), hasil perhitungan didapat sampel 88 anak balita. Teknik pengambilan sampel dengan cara cluster, dengan titik pusat cluster rumah ketua RT, sampel diambil dengan cara melingkar atau obat nyamuk. Sampel diambil dari rumah tangga yang yang mempunyai anak balita umur 6-59 bulan dengan jumlah balita per cluster 11 anak. Analisis data mengunakan uji chi-square.

\section{HASIL}

\section{A. ANALISIS UNIVARIAT}

\section{Distribusi Frekuensi Status Gizi $(\mathrm{TB} / \mathrm{U})$ pada Balita}

Pengukuran status gizi balita pada penelitian ini dilakukan dengan mengukur tinggi badan (untuk balita usia $>2$ tahun) ataupun panjang badan (untuk balita usia <2 tahun). Hasil mengenai distribusi status gizi (TB/U) pada balita di Kelurahan Beringin Jaya dapat dilihat pada tabel 1:

Tabel 1. Distribusi Frekuensi Status Gizi (TB/U) pada Balita

\begin{tabular}{lcc}
\hline \multirow{2}{*}{ Status Gizi } & \multicolumn{2}{c}{ Total } \\
\cline { 2 - 3 } Sangat pendek & Jumlah & $\mathbf{\%}$ \\
Pendek & 19 & 0 \\
Normal & 69 & 78,6 \\
Tinggi & 0 & 0 \\
\hline Jumlah & 88 & 100 \\
\hline
\end{tabular}

Berdasarkan analisa yang telah dilakukan pada balita didapatkan hasil jumlah responden dengan status gizi tinggi tidak ada, jumlah responden dengan status gizi normal sebanyak 69 orang $(8,5 \%)$, jumlah responden dengan status gizi pendek sebanyak 19 orang $(21,6 \%)$ dan jumlah balita dengan status gizi sangat pendek tidak ada. Kategori pendek dan sangat pendek dikategorikan menjadi stunting.

\section{Distribusi Frekuensi Asupan Energi Balita}

Berdasarkan hasil penelitian yang telah dilakukan, asupan energi diperoleh dengan recall $2 \times 24$ jam secara berturut-turut. Hasil recall dibandingkan dengan angka kecukupan energi (AKE), sehingga diperoleh asupan energi pada balita rata-rata perhari. Distribusi asupan energi dapat dilihat pada tabel 2.

Tabel 2. Distribusi Frekuensi Asupan Energi Balita

\begin{tabular}{lcc}
\hline \multirow{2}{*}{ Status Gizi } & \multicolumn{2}{c}{ Total } \\
\cline { 2 - 3 } & Jumlah & \% \\
\hline Sangat kurang & 26 & 29,5 \\
Kurang & 47 & 53,4 \\
Normal & 15 & 17 \\
Lebih & 0 & 0 \\
\hline Jumlah & 88 & 100 \\
\hline
\end{tabular}


Berdasarkan tabel diatas dapat diketahui asupan energi balita yaitu sangat kurang berjumlah 26 balita $(29,5 \%)$, kurang berjumlah 47 balita $(53,4 \%)$, dan normal berjumlah 15 balita (17\%).

\section{Distribusi frekuensi Asupan Protein}

Berdasarkan hasil penelitian yang telah dilakukan, asupan protein diperoleh dengan recall $2 \times 24$ jam secara berturut-turut. Hasil recall dibandingkan dengan angka kecukupan protein (AKP), sehingga diperoleh asupan protein pada balita rata-rata perhari. Distribusi asupan protein dapat dilihat pada tabel 3

\section{Tabel 3. Distribusi Frekuensi Asupan} Protein Balita

\begin{tabular}{lcc}
\hline \multirow{2}{*}{ Status Gizi } & \multicolumn{2}{c}{ Total } \\
\cline { 2 - 3 } & Jumlah & \% \\
\hline Sangat kurang & 9 & 10,2 \\
Kurang & 33 & 37,5 \\
Normal & 46 & 52,3 \\
Lebih & 0 & 0 \\
\hline Jumlah & 88 & 100 \\
\hline
\end{tabular}

Berdasarkan tabel di atas dapat diketahui asupan protein balita di Kelurahan Beringin Jaya yaitu sangat kurang berjumlah 9 balita $(10,2 \%)$, kurang berjumlah 33 balita $(37,5 \%)$, dan normal berjumlah 46 balita $(52,3 \%)$.

\section{Distribusi Frekuensi Pemberian Eksklusif}

Berdasarkan hasil penelitian yang telah dilakukan, pemberian ASI Eksklusif diperoleh dengan kuesioner. Distribusi pemberian ASI Eksklusif dapat dilihat pada tabel dibawah ini:

Tabel 4. Distribusi Frekuensi Pemberian ASI Eklusif

\begin{tabular}{lcc}
\hline \multirow{2}{*}{ ASI Eklusif } & \multicolumn{2}{c}{ Total } \\
\cline { 2 - 3 } & Jumlah & \% \\
\hline TidakASI Eklusif & 51 & 58 \\
ASI Eklusif & 37 & 42 \\
\hline Jumlah & 88 & 100 \\
\hline
\end{tabular}

Berdasarkan tabel di atas dapat diketahui pemberian ASI Eksklusif balita di Kelurahan Beringin Jaya yaitu tidak ASI Eksklusif berjumlah 51 balita (58\%) dan ASI Eksklusif berjumlah 37 balita (42\%).

ASI

\section{Distribusi Frekuesi Pengetahuan Ibu Balita}

Berdasarkan hasil penelitian yang telah dilakukan, pengetahuan ibu diperoleh dengan kuesioner yang berisikan pertanyaan-pertanyaan mengenai gizi. Distribusi pengetahuan ibu dapat dilihat pada tabel 5:

Tabel 5. Pengetahuan Ibu

\begin{tabular}{lcc}
\hline Pengetahuan & \multicolumn{2}{c}{ Total } \\
\cline { 2 - 3 } Ibu & Jumlah & \% \\
\hline Kurang & 14 & 15,9 \\
Cukup & 55 & 62,5 \\
Baik & 19 & 21,6 \\
\hline Jumlah & 88 & 100 \\
\hline
\end{tabular}

Berdasarkan tabel di atas dapat diketahui pengetahuan ibu balita di Kelurahan Beringin Jaya yaitu kurang sebanyak 14 ibu balita $(15,9 \%)$, cukup berjumlah 55 ibu balita $(62,5 \%)$, dan baik sebanyak 19 ibu balita $(21,6 \%)$.

\section{B. ANALISIS BIVARIAT}

\section{Hubungan Asupan Energi dengan Status Gizi Balita (TB/U)}

Hasil analisis analisa bivariat mengenai hubungan asupan energi dengan status gizi balita $(\mathrm{TB} / \mathrm{U})$ dapat dilihat pada tabel 6 :

\begin{tabular}{|c|c|c|c|c|c|c|c|}
\hline \multirow{3}{*}{$\begin{array}{c}\text { Asupan } \\
\text { Energi }\end{array}$} & \multicolumn{4}{|c|}{ Status Gizi } & \multirow{2}{*}{\multicolumn{2}{|c|}{ Total }} & \multirow{3}{*}{$\begin{array}{c}p- \\
\text { value }\end{array}$} \\
\hline & \multicolumn{2}{|c|}{ Stunting } & \multicolumn{2}{|c|}{ Normal } & & & \\
\hline & $\mathbf{n}$ & $\%$ & $\mathrm{n}$ & $\%$ & $\mathrm{n}$ & $\%$ & \\
\hline Kurang & 18 & 24,7 & 55 & 75,3 & 73 & 100 & \multirow{3}{*}{0,175} \\
\hline Normal & 1 & 6,7 & 14 & 93,3 & 15 & 100 & \\
\hline Jumlah & 19 & 21,6 & 69 & 78,4 & 88 & 100 & \\
\hline
\end{tabular}

Hasil analisis diketahui bahwa asupan energi kurang dengan status gizi stunting sebanyak 18 balita (24,7\%), sedangkan asupan energi normal dengan status gizi stunting sebanyak 1 balita $(6,7 \%)$. Berdasarkan uji statistik dengan menggunakan khi kuadrat dengan tingkat kepercayaan 95\% maka diperoleh $p$-value yaitu $0,175 \quad(p>0,05)$. Hal ini menunjukkan bahwa tidak ada hubungan yang bermakna antara asupan energi dengan status gizi balita (TB/U) di Kelurahan Beringin Jaya. 


\section{Hubungan Asupan Protein dengan Status Gizi Balita (TB/U)}

Hasil analisis hubungan asupan protein dengan status gizi balita dapat dilihat pada tabel 7 berikut.

Tabel 7. Hubungan Asupan Protein dengan Status Gizi

\begin{tabular}{|c|c|c|c|c|c|c|c|}
\hline \multirow{3}{*}{$\begin{array}{c}\text { Kategori } \\
\text { Asupan } \\
\text { protein }\end{array}$} & \multicolumn{4}{|c|}{ Status gizi } & \multirow{2}{*}{\multicolumn{2}{|c|}{ Total }} & \multirow{3}{*}{$\begin{array}{c}p- \\
\text { value }\end{array}$} \\
\hline & \multicolumn{2}{|c|}{ Stunting } & \multicolumn{2}{|c|}{ Normal } & & & \\
\hline & $\mathbf{n}$ & $\%$ & $\mathbf{n}$ & $\%$ & $\mathbf{n}$ & $\%$ & \\
\hline Kurang & 14 & 33,3 & 28 & 66,7 & 42 & 100 & \\
\hline Normal & 5 & 10,9 & 41 & 89,1 & 46 & 100 & 0,022 \\
\hline Jumlah & 19 & 21,8 & 69 & 78,4 & 88 & 100 & \\
\hline
\end{tabular}

Hasil penelitian didapatkan balita dengan asupan protein kurang dengan status gizi stunting sebanyak 14 balita $(33,3 \%)$, sedangkan asupan protein baik dengan status gizi stunting sebanyak 5 balita (10,9\%). Berdasarkan uji statistik dengan menggunakan chi square dengan tingkat kepercayaan 95\% maka diperoleh $p$-value yaitu $0,022 \quad(p<0,05)$. Hal ini menunjukkan bahwa ada hubungan yang bermakna antara asupan protein dengan status gizi balita $(\mathrm{TB} / \mathrm{U})$.

\section{Hubungan Pemberian ASI Eksklusif dengan Status Gizi (TB/U)}

Tabel 8. Hubungan Pemberian ASI Ekskulsif Dengan Status Gizi Balita (TB/U)

\begin{tabular}{|c|c|c|c|c|c|c|c|}
\hline \multirow{3}{*}{$\begin{array}{c}\text { Pemberian } \\
\text { ASI } \\
\text { Eksklusif }\end{array}$} & \multicolumn{4}{|c|}{ Status Gizi } & \multirow{2}{*}{\multicolumn{2}{|c|}{ Total }} & \multirow{3}{*}{$\begin{array}{c}p- \\
\text { value }\end{array}$} \\
\hline & \multicolumn{2}{|c|}{ Stunting } & \multicolumn{2}{|c|}{ Normal } & & & \\
\hline & $\mathbf{n}$ & $\%$ & $\mathbf{n}$ & $\%$ & n & $\%$ & \\
\hline $\begin{array}{l}\text { Tidak ASI } \\
\text { Eksklusif }\end{array}$ & 12 & 23,5 & 39 & 76,5 & 51 & 100 & \multirow{3}{*}{0,022} \\
\hline $\begin{array}{c}\text { ASI } \\
\text { Eksklusif }\end{array}$ & 7 & 18,9 & 30 & 81,1 & 37 & 100 & \\
\hline Jumlah & 19 & 21,6 & 69 & 79,4 & 88 & 100 & \\
\hline
\end{tabular}

Hasil penelitian menunjukkan bahwa asupan balita tidak ASI Eksklusif dengan status gizi stunting sebanyak 12 balita $(23,5 \%)$, sedangkan balita yang ASI Eksklusif dengan status gizi stunting sebanyak 7 balita $(18,9 \%)$. Berdasarkan uji statistik diperoleh $p$-value yaitu $0,798$ ( $p>0,05)$, yang menunjukkan bahwa tidak ada hubungan yang bermakna antara pemberian ASI Eksklusif dengan status gizi balita/stunting.

\section{Hubungan Pengetahuan Ibu dengan Status GiziBalita (TB/U)}

Tabel 9. Hubungan Pengetahuan Ibu dengan Status Gizi Balita (TB/U)

\begin{tabular}{|c|c|c|c|c|c|c|c|}
\hline \multirow{3}{*}{$\begin{array}{c}\text { Penge- } \\
\text { tahuan } \\
\text { Ibu }\end{array}$} & \multicolumn{4}{|c|}{ Staus Gizi } & \multirow{2}{*}{\multicolumn{2}{|c|}{ Total }} & \multirow{3}{*}{$\begin{array}{c}p- \\
\text { value }\end{array}$} \\
\hline & \multicolumn{2}{|c|}{ Stunting } & \multicolumn{2}{|c|}{ Normal } & & & \\
\hline & $\mathrm{n}$ & $\%$ & $\mathrm{n}$ & $\%$ & $\mathrm{n}$ & $\%$ & \\
\hline Kurang & 12 & 23,5 & 39 & 76,5 & 51 & 100 & \\
\hline Baik & 7 & 18,9 & 30 & 81,1 & 37 & 100 & 0,798 \\
\hline Jumlah & 19 & 21,6 & 69 & 79,4 & 88 & 100 & \\
\hline
\end{tabular}

Hasil analisis bivariat antara pengetahuan ibu dengan status gizi balita di Kelurahan Beringin Jaya didapatkan hasil pengetahuan ibu yang kurang dengan status gizi balita stunting sebanyak 15 balita $(21,7 \%)$, sedangkan pengetahuan ibu yang baik dengan status gizi balita stunting sebanyak 4 balita $(21,1 \%)$. Berdasarkan uji statistik diperoleh $\mathrm{p}$ value yaitu $1.000(p>0,05)$. Hal ini menunjukkan ada hubungan yang bermakna antara pengetahuan ibu dengan status gizi balita (TB/U).

\section{PEMBAHASAN}

\section{Status Gizi Balita (TB/U)}

Hasil penelitian menunjukkan sebesar $21,6 \%$ balita memiliki status gizi stunting. Pada proses penggabungan data kategori status gizi digabungkan menjadi dua kategori, yaitu stunting dan normal, dimana status gizi sangat pendek dan pendek menjadi satu disebut dengan stunting. Persentase stunting di Kelurahan Beringin Jaya lebih tinggi dibandingkan dengan persentase stunting di Kecamatan Kemiling sebesar 20,9\% dan di kota Bandar Lampung sebesar 17,3\% (Riskesdas, 2013).

Hasil penelitian ini sejalan dengan hasil penelitian Anisa (2012) di Depok bahwa balita pendek pada usia kurang dari 59 bulan ditemukan berada pada resiko yang lebih besar mengalami status gizi pendek yang menunjukkan hasil analisis univariat sebesar 21,2\%. Hal tersebut menunjukkan bahwa masalah gizi pendek pada usia kurang dari 59 bulan di Kelurahan Beringin Jaya telah menjadi masalah kesehatan masyarakat, karena berada diatas batas yang telah ditetapkan oleh WHO yaitu sebesar $20 \%$.

Masalah gizi pendek yang terjadi pada balita dapat terjadi karena banyak faktor seperti kurang asupan energi dan protein, pola pemberian makanan, konsumsi makanan yang 
tidak beraneka ragam dan tidak seimbang, sikap ibu, kurang pengetahuan terkait makanan dan gizi dan faktor lainnya. Menurut Branca F dan Ferrari M (2002); Gibson RS (2005) mengemukakan kependekan/stunting disebabkan konsumsi makanan yang tidak cukup berlangsung lama sehingga asupan zat gizi makro dan mikro berkurang. Menurut Engle et al. 1997 dalam Lamid 2015 menyatakan bahwa penyebab pengasuhan orang tua terutama ibu sangat penting dalam memberikan perawatan anak bila sakit, pemberian makan, da memberikan stimulasi kepada anak.

Dampak lain kependekan berisiko tinggi menurunkan tingkat kecerdasan, produktivitas serta kualitas sumber daya manusia di masa depan. Selain ini kependekan juga berisiko menimbulkan penyakit degenerative pada usia dewasa (Lamid, 2015).

\section{Hubungan Asupan Energi dengan Status Gizi Balita (TB/U)}

Berdasarkan hasil penelitian yang telah dilakukan di Kelurahan Beringin Jaya diketahui rata-rata asupan energi balita 907,26 kkal. Balita asupan energi kurang dengan status gizi pendek sebanyak 18 balita $(24,7 \%)$, sedangkan asupan energi normal dengan status gizi pendek sebanyak 1 balita $(6,7 \%)$.

Berdasarkan uji statistik dengan menggunakan chi square dengan tingkat kepercayaan $95 \%$ maka diperoleh $p$-value yaitu $0,175(p>0,05)$. Hal ini menunjukkan bahwa hipotesis 0 diterima yang berarti tidak ada hubungan yang bermakna antara asupan energi dengan status gizi balita (TB/U). Hal ini sejalan dengan penelitian Anisa (2010), yang menunjukkan tidak adanya hubungan yang bermakna antara asupan energi dengan kejadian stunting pada balita di Kelurahan Kalibiru, hal ini dapat dilihat dari nilai $p=0,342(p>0,05)$. Berdasarkan teori asupan makanan bukan satu-satunya penyebab stunting, tetapi penyebab multifactorial. Faktor-faktor seperti kemiskinan, kepadatan penduduk dan kemungkinan kontaminasi makanan serta penyakit infeksi dapat berdampak pada status kesehatan anak (Theron et al., 2004).

Hal ini berbeda dengan penelitian Muchlis (2011), hubungan asupan energi dengan status gizi balita menunjukkan adanya hubungan yang bermakna antara asupan energi dengan status gizi di Kelurahan Tamamaung Kota Makassar, hal ini dapat dilihat dari nilai $p=0,027 \quad(p<0,05)$. Kebutuhan energi anak diantaranya digunakan untuk meningkatkan berat badan, meningkatkan pertumbuhan dan perkembangan, melakukan aktifitas fisik, mengatur suhu tubuh, metabolisme makanan, serta untuk proses penyembuhan dari sakit (Sulistyoningsih, 2011).

Berdasarkan hasil penelitian didapatkan tidak adanya hubungan yang bermakna antara asupan energi dengan status gizi balita pada penelitian ini pada proses recall, daya ingat ibu balita dalam menceritakan asupan makanan anaknya 24 jam yang lalu. Selain itu, keterbatasan peneliti dalam proses recall tidak membawa alat ukuran rumah tangga (URT) untuk memudahkan peneliti dalam mengestimasi bahan makanan. Prinsip dari metode recall yaitu dilakukan dengan mencatat jenis dan jumlah bahan makanan yang dikonsumsi pada periode 24 jam lalu. Recall 24 jam data yang diperoleh cenderung besifat kualitatif. Oleh karena itu, untuk mendapatkan data kuantitatif, maka jumlah konsumsi makanan individu ditanyakan secara teliti dengan menggunakan alat URT (sendok, gelas, piring, dll) (Supariasa, 2012). Faktor lain yaitu instrument yang digunakan yaitu food recall 2x24 jam, sebaiknya recall dilakukan minimal dua kali dengan tidak berturut-turut. Recall yang dilakukan sebanyak satu kali kurang dapat menggambarkan kebiasaan makan seseorang (Supariasa, 2012) dan standar pembanding yang digunakan yaitu menggunakan Angka Kecukupan Gizi (AKG), untuk mandapatkan hasil yang baik menggunakan pembanding sesuai kebutuhan balita. Dalam penelitian ini status gizi yang di lihat yaitu TB/U (stunting) yang dimana anak stunting menggambarkan kejadian masa lalu sehingga asupan energi balita tidak dapat mempengaruhi $\mathrm{TB} / \mathrm{U}$ akan tetapi lebih mempengaruhi $\mathrm{BB} / \mathrm{U}$.

Kurangnya asupan energi balita dikelurahan Beringin Jaya kurang, berdasarkan wawancara recall yang didapatkan yaitu balita cenderung mengkosumsi makanan pokok yang sedikit, tidak beragam dan kebiasaan makan 12 kali dalam 1 hari. Selain itu rata-rata balita suka mengkonsumsi jajanan ringan yang mengandung kandungan gizi yang rendah seperti wafer tango, richesse nabati, permen dll. Selain itu dari hasil wawancara sebanyak $20 \%$ didapatkan masalah dari faktor ibu balita yang kurang kreatif dan komunikasi dalam memberikan makanan kepada anak sehingga ketika anak tidak mau makan dan ibu balita pun berhenti memberikan makanan sehingga asupan yang didapat anak tersebut kurang dari kebutuhan. 


\section{Hubungan Asupan Protein dengan Status Gizi $(\mathrm{TB} / \mathrm{U})$}

Rata-rata asupan protein balita berdasarkan hasil penelitian sebesar 24,1 gram. Balita asupan protein yang kurang dengan status gizi stunting sebanyak 14 balita $(33,3 \%)$, sedangkan asupan protein normal dengan status gizi stunting sebanyak 5 balita (10,9\%).

Berdasarkan uji statistik dengan menggunakan khi kuadrat dengan tingkat kepercayaan $95 \%$ maka diperoleh $p$-value yaitu $0,022(p<0,05)$, yang artinya ada hubungan yang bermakna antara asupan protein dengan status gizi balita (TB/U) di Kelurahan Beringin Jaya. Hasil penelitian ini sesuai dengan penelitian Anisa (2012), yang menunjukkan adanya hubungan yang bermakna antara asupan protein dengan kejadian stunting pada balita di Kelurahan Kalibiru, hal ini dapat dilihat dari nilai $p=0,011 \quad(p<0,05)$.

Berdasarkan penelitian yang telah dilakukan, dapat dilihat sebagian besar asupan protein pada balita pendek masih kurang. Adanya hubungan bermakna antara asupan protein dengan status gizi ini disebabkan karena rata-rata balita hanya mengkonsumsi lauk pauk 1-2 kali/hari dengan jumlah yang sedikit. Adapun balita yang hanya mengkonsumsi nasi dan sayur saja, sehingga asupan protein tidak tercukupi. Berdasarkan teori asupan protein yang kurang akan menyebabkan terhambatnya pertumbuhan jaringan dan organ serta terhambatnya pertumbuhan yang akan berpengaruh terhadap tinggi badan, berat badan, dan lingkar kepala (Sulistyoningsih, 2011).

\section{Hubungan Pemberian ASI Eksklusif dengan Status Gizi Balita(TB/U)}

Berdasarkan hasil penelitian yang telah dilakukan balita di Kelurahan Beringin Jaya diketahui balita tidak ASI Eksklusif dengan status gizi stunting sebanyak 12 balita $(23,5 \%)$, sedangkan balita yang ASI Eksklusif dengan status gizi stunting sebanyak 7 balita $(18,9 \%)$. Hasil uji statistic diperoleh $\mathrm{p}$ value yaitu 0,798 ( $>>0,05)$. Hal ini menunjukkan bahwa tidak ada hubungan yang bermakna antara pemberian ASI Eksklusif dengan status gizi balita/stunting. Hal ini sesuai dengan penelitian Anisa (2012), yang menunjukkan tidak adanya hubungan yang bermakna antara pemberian ASI Eksklusif dengan kejadian stunting pada balita di Kelurahan Kalibiru, dengan nilai $\mathrm{p}=0,771$ $(p>0,05)$. Penelitian ini juga tidak berbeda dengan penelitian Andjani, dkk (2010) yang menunjukan tidak adanya hubungan antara pemberian ASI Eksklusif dengan status gizi balita, dikarenakan sebagian besar ibu yang tidak memberikan ASI Eksklusif disebabkan oleh tingkat pengetahuan yang kurang. Pendidikan pada satu sisi mempunyai dampak positif yaitu ibu mengerti akan pentingnya pemeliharaan kesehatan termasuk pemberian ASI Eksklusif. Rendahnya tingkat pengetahuan ibu tentang ASI menyebabkan ibu tidak memberikan ASI Eksklusif kepada bayinya hal ini akan mempengaruhi status gizi balitanya. Tidak selalu bayi yang tidak ASI Eksklusif mempunyai status gizi yang lebih buruk atau kurang dari bayi dengan ASI Eksklusif.

ASI Eksklusif tidak selalu menjadi faktor yang mempengaruhi status gizi, melainkan ada faktor-faktor yang lebih mempengaruhi status gizi itu sendiri (Anisa, 2012). Faktor-faktor tersebut sangat terkait dengan tingkat pendidikan, pengetahuan, dan keterampilan keluarga. Semakin tinggi tingkat pendidikan, pengetahuan, dan keterampilan keluarga makin baik tingkat ketahanan pangan keluarga, semakin baik pola pengasuhan anak dan keluarga makin banyak memanfaatkan pelayanan yang ada. Ketahanan pangan keluarga juga terkait dengan ketersediaan pangan, harga pangan dan daya beli keluarga, serta pengetahuan tentang gizi dan kesehatan (Waryana, 2010).

Hal ini berbeda dengan penelitian Rohmatun (2014), yang menunjukan adanya hubungan yang bermakna antara pemberian ASI Eksklusif dengan kejadian stunting pada balita di Desa Sidowarno Kecamatan Wonosari, hal ini dapat dilihat dari nilai $p=0,045(p>0,05)$.

ASI adalah makanan terbaik untuk bayi.ASI sangat dibutuhkan untuk kesehatan anak dan mendukung pertumbuhan dan perkembangan bayi secara optimal. Bayi yang mendapatkan ASI Eksklusif akan terpenuhi kebutuhan gizinya secara maksimal sehingga anak akan lebih sehat, lebih tahan terhadap infeksi, tidak mudah terkena alergi. Anak yang mendapat ASI Eksklusif akan mengalami pertumbuhan dan perkembangan yang optimal (Sulistyoningsih, 2011).

Hasil analisis data yang telah dilakukan didapat bahwa, tidak adanya hubungan antara pemberian ASI Eksklusif dengan status gizi yaitu disebabkan oleh beberapa faktor diataranya sebagian besar balita (58\%) di Kelurahan Beringin Jaya tidak ASI Eksklusif, rata-rata umur responden balita 2-3 tahun sehingga daya ingat ibu balita mengenai pemberian ASI Eksklusif khususnya ibu yang memiliki balita diatas dua tahun. 
Hasil wawancara kepada ibu balita, didapatkan berbagai macam faktor/alasan ibu balita tidak memberikan ASI Eksklusif kepada anaknya yaitu sebagian ibu balita memiliki kebiasaan memberikan makanan kepada anak sebelum 6 bulan. Jenis makanan yang diberikan sepeti susu formula, bubur sun, pisang, madu, air putih. Alasan ibu balita memberikan makanan tersebut antara lain ASI tidak keluar, agar anak tidak lapar sehingga mudah tidur, ibu bekerja, ibu menganggap susu formula lebih praktis sehingga anak diberikan susu formula sehingga sebagian besar balita kebutuhan ASI Eksklusif tidak terpenuhi. Kandungan protein dalam ASI cukup tinggi. Salah satu fungsi protein yaitu sebagai zat pembangun bagi pertumbuhan dan pemeliharaan jaringan tubuh (Kartasapoetra, 2010).

Protein yang terdapat pada ASI dan susu sapi terdiri atas protein whey dan casein. Didalam ASI, lebih banyak terdapat protein whey yang lebih mudah diserap oleh usus bayi. Sedangkan casein cenderung lebih susah dicerna oleh usus bayi, yang banyak terkandung dalam susu sapi (Khamzah, 2012).

\section{Hubungan Pengetahuan Ibu dengan Status Gizi Balita (TB/U)}

Dari hasil penelitian diketahui pengetahuan ibu yang kurang dengan balita status gizi stunting sebanyak $15 \quad(21,7 \%)$, sedangkan balita status gizi normal sebanyak 54 $(78,9 \%)$. Pengetahuan ibu yang baik dengan balita status gizi stunting sebanyak $4(21,1 \%)$, sedangkan status gizi normal sebanyak 15 balita $(78,9 \%)$. Berdasarkan ujistatistik diperoleh pvalue yaitu $1.000 \quad(\mathrm{p}>0,05)$ maka dapat disimpulkan bahwa tidak adanya hubungan yang bermakna antara pengetahuan ibu dengan status gizi (stunting).Hal ini sesuai dengan penelitian Kawengian (2015), yang menunjukkan tidak adanya hubungan yang bermakna antara pengetahuan dengan status gizi balita $(\mathrm{TB} / \mathrm{U})$ Desa Mopusi Kecamatan Lolayan Kabupaten Bolaang Mongondow Induk. Hal ini dapat dilihat dari nilai $p=0,113(p>0,05)$.

Hasil penelitian ini berbeda dengan penelitian Marniasih (2015), yang menunjukkan adanya hubungan yang bermakna antara pengetahuan ibu dengan kejadian stunting pada batita di Desa Pandan Indah Kecamatan Praya Daya Kabupaten Lombok Tengah NTB.
Hal ini didapat dilihat dari nilai $p=0,0001$ $(p<0,05)$. Pengetahuan merupakan hasil dari tahu, dan ini terjadi setelah orang melakukan pengindraan terhadap suatu objek tertentu. Sebagian besar pengetahuan manusia diperoleh melalui mata dan telinga. Pengetahuan atau kognitif domain yang sangat penting dalam membentuk tindakan seseorang (Notoadmodjo, 2013).

Selain itu, tidak adanya hubungan antara pengetahuan ibu dengan status gizi diketahui dari hasil wawancara ibu balita mengenai pengetahuan gizi, sebagian besar ibu balita memiliki pengetahuan rendah, sehingga pengetahuan akan gizi yang baik untuk anak tidak diterapkan didalam kehidupan sehari-hari. Pengetahuan gizi bukan merupakan faktor langsung yang mempengaruhi stunting.faktor langsung yang mempengaruhi stunting yaitu penyakit infeksi, pemberian ASI Eksklusif, ketersediaan makanan, dan faktor rumah tangga dan keluarga (Lamid, 2015).

\section{SIMPULAN}

Hasil penelitian ini menunjukkan adanya hubungan bermakna antara asupan protein dengan stunting $p$-value $=0,022 \quad(p<0,05$. Sementara untuk variabel asupan energi dengan stunting ( $p$-value $=0,175),(p>0,05)$. Tidak adanya hubungan yang bermakna antara pemberian ASI Eksklusif dengan stunting $p$-value $=0,758 \quad(p$ value $>0,05)$. Tidak adanya hubungan yang bermakna antara pengetahuan ibu dengan stunting $p$-value $=1.000$ ( $p$-value $>0,05)$.

\section{SARAN}

Berdasarkan simpulan di atas, peneliti memberikan beberapa saran antara lain: Diharapkan puskesmas dan posyandu dapat meningkatkan kegiatan yang berkaitan dengan penyuluhan mengenai ASI Eksklusif dan demonstrasi pembuatan Makanan Pendamping ASI (MP-ASI) agar masyarakat memahami cara pembuatan MP-ASI yang sehat dan bergizi untuk anak dan kegiatan penyuluhan mengenai pentingnya periode emas 1000 hari kehidupan khususnya bagi wanita usia subur dan ibu hamil agar menurunkan resiko anak stunting. 


\section{DAFTAR PUSTAKA}

Andajani, Susilowati. 2010. Hubungan Antara Pengetahuan Ibu Tentang Gizi dan Pemberian ASI Eksklusif dengan Status Gizi Anak 7-36 Bulan di POSYANDU Delima 2 Dusun Sanan Desa Watugede Kecamatan Singosari Kabupaten Malang. Naskah Publikasi. Yogyakarta: Sekolah Tinggi Ilmu Kesehatan Aisyah Yogyakarta.

Anisa. 2012. Faktor-faktor yang berhubungan dengan kejadian Stunting pada balita usia 25-60 bulan di Kelurahan Kalibaru Depok, [Skripsi]. Depok: Fakultas Kesehatan Masyarakat, Universitas Indonesia.

Branca, F. dan Ferrari, M. 2002. Impact of Micronutrient Defeciencies on Growth: The Stunting Syndrome.

Dinas Kesehatan Lampung. 2014. Profil Kesehatan Provinsi Lampung Tahun 2014. Lampung.

Jeanette. 2014. Hubungan Asupan Energi dengan Kejadian Stunting pada anak usia 13-36 Bulan di Wilayah Kerja Puskesmas Tuminting Kota Manado. [Skripsi]. Manado: Fakultas Kesehatan Masyarakat Universitas Sam Ratulangi.

Kartasapoetra, Marsetyo. 2010. Ilmu Gizi. Jakarta: Rineka Cipta

Kawengian, S. E., \& Kapantow, N. H. 2015. Hubungan Antara Pengetahuan Ibu Tentang Gizi Dengan Status Gizi Anak Umur 1-3 Tahun Di Desa Mopusi Kecamatan Lolayan Kabupaten Bolaang Mongondow Induk Sulawesi Utara. eBiomedik, 3(2).

Khamzah, Nur, 2012. Segudang Keajaiban ASI yang Harus Anda Ketahui. PT Flash Book

Lamid, Astuti. 2015. Masalah Stunting pada Anak Balita. Bogor: Penerbit IPB Press.

Lemeshow, dkk. 1997. Besar Sampel dalam Penelitian Kesehatan. Yogyakarta: Gajah Mada University Press.

Marniasih. 2015. Faktor-faktor yang berhubungan dengan kejadian Stunting pada Batita usia 12-35 Bulan di desa Pandan Indah Kecamatan Praya Barat Daya Kabupaten Lombok Tengah Nusa Tenggara Barat. Artikel Penelitian. Ungaran: Sekolah Tinggi Ilmu Kesehatan Ngudi Waluyo Ungaran.
Muchlis, dkk. 2011. Hubungan Asupan Energy dan Protein dengan Status Gizi Balita di Kelurahan Tamamaung. Artikel Penelitian. Makassar: Program Studi Ilmu Gizi Universitas Hasanudin Makassar. http://repository.unhas.ac.id/bitstream/han dle/123456789/7908/NOVAYENI\%20MU CHLIS\%20K21106024.pdf?s

Notoatmodjo, Soekidjo. 2013. Promosi Kesehatan dan Perilaku Kesehatan. Jakarta: Rineka Cipta.

Riskesdas. 2013. Laporan Nasional Riset Kesehatan Dasar (Riskesdas) Tahun 2013. Badan penelitian dan Pengembangan Kesehatan Departemen Kesehatan RI. Jakarta.

Rohmatun. 2014. Hubungan Tingkat Pendidikan Ibu dan Pemberian ASI Eksklusif dengan kejadian Stunting pada Balita di Desa Sidowarno Kecamatan Wonosari Kabupaten Klaten. Naskah Publikasi, Fakultas Ilmu Kesehatan Masyarakat Uiversitas Muhammadiyah Surakarta.

Sulistyoningsih, Hariyani. 2011. Gizi untuk Kesehatan Ibu dan Anak. Yogyakarta: Graha Ilmu

Supariasa, et al. 2012. Penilaian Status Gizi. Jakarta: Penerbit Buku Kedokteran EGC.

Terati S, Sartono, Nazarena, Yunita. 2013. Studi determi-nan kejadian stunting pada anak balita pengunjung posyandu wilayah kerja Dinas Kesehatan Kota Palembang. [Tesis]. Yogyakarta: Universitas Gadjah Mada.

Theron, M, et al. 2004. Inadequate Dietary Intake is Not The Cause of Stunting Amongst Young Children Living in an Informal Settlemen in Gauteng and Rulal Limpopo Province in South Africs: The Nutrigro Study. Public Health Nutritionist. www.ncbi.nlm.nih.gov (Diakses pada 11 Maret 2012)

Unicef Indonesia. 2012. Ringkasan Kajian Gizi Ibu dan Anak. Jakarta. Diunduh dari https://www.unicef.org/indonesia/id/A6 B_Ringkasan_Kajian_Gizi.f

Waryana. 2010. Gizi Reproduksi. Yogyakarta: Pustaka Rihama.

World Health Organization (WHO). 2016. Child Stunting. http://who.int/gho/publications/world_heal th_statistics/en/ 